\title{
Perbandingan Keekonomian Transmisi HVDC dan Pengangkutan Batubara Dalam Pengembangan Kelistrikan Kalimantan - Sulawesi
}

\section{Edwaren Liun*}

Pusat Kajian Sistem Energi Nuklir, BATAN, JI. Kuningan Barat, Jakarta, Indonesia

\begin{tabular}{l}
\hline INFORMASI ARTIKEL \\
\hline Riwayat Artikel: \\
Diterima: \\
22 Desember 2016 \\
Diterima dalam bentuk revisi: \\
14 Februari 2017 \\
Disetujui: \\
1 Maret 2017 \\
\end{tabular}

Kata kunci:

HVDC,

Daerah terpencil,

Pembangkit listrik,

Efektif,

Efisien.

\begin{abstract}
ABSTRAK
PERBANDINGAN KEEKONOMIAN TRANSMISI HVDC DAN PENGANGKUTAN BATUBARA DALAM PENGEMBANGAN KELISTRIKAN KALIMANTAN - SULAWESI. Sehubungan dengan karakteristik beban pada banyak wilayah di Indonesia, sistem kelistrikan sering tidak efisien. Di daerah yang jauh dari jaringan interkoneksi dan pulau terpencil misalnya, pemilihan jenis pembangkit berbahanbakar murah seperti batubara tidak tidak dapat diterapkan, sedangkan pembangkit berbahanbakar minyak biayanya sangat tinggi dan memberatkan beban subsidi. Akibatnya daerah tersebut tetap menggunakan pembangkit berbahanbakar minyak dengan membatasi waktu nyala pembangkit dan konsumen tidak mendapat layanan memuaskan. Makalah ini bertujuan untuk menganalisis sejauh mana kemanfaatan sistem transmisi HVDC dari Kalimantan ke Sulawesi sehingga konsumen mendapat layanan lebih baik dan dapat berproduksi untuk meningkatkan kesejahteraan. Metode yang digunakan dalam analisis ini adalah penelusuran pustaka dan melakukan perhitungan berdasarkan formula yang ada. Hasil yang diperoleh bahwa segi biaya langsung, sistem HVDC yang meliputi biaya saluran transmisi, konverter dan rugi-rugi daya berkisar antara 0,46 - 0,60 USD $4 / k W h$ untuk kapasitas daya berkisar antara 500 - 2000 MWe. Sedangkan biaya angkut batubara berkisar antara 0,544 0,645 USD $\$ / k W h$ untuk tongkang berukuran panjang antara $270-330$ feet. Dengan demikian, untuk wilayah Indonesia dengan banyak pulau dan daerah terpencil memungkinkan secara lebih ekonomis untuk menyalurkan listrik dengan transmisi HVDC dari pulau atau daerah yang sistem listriknya telah berkembang, sehingga wilayah terpencil juga mendapat layanan listrik yang prima untuk meningkatkan kesejahteraan dan pendapatan penduduknya.
\end{abstract}

\begin{abstract}
ECONOMIC COMPARISON OF HVDC TRANSMISSION AND COAL TRANSPORT FOR KALIMANTAN - SULAWESI POWER SYSTEM EXPANSION. Due to the load characteristics on many regions in Indonesia, the electrical system is often inefficient. In areas far from an interconnected network, for example isolated island, the choice of low cost fueled plants such as coal can not be applied, while the oil fueled has a very high generation cost and high burdened on subsidies. As a result, those area are still use oil fueled plant by limiting the generator flame time and consumers do not receive satisfactory service. This paper aims to analyze the extent to which the benefit of HVDC transmission system from Kalimantan to Sulawesi so that consumers could get better services and able to produce in order to improve their welfare. The method used in this analysis is a literature study and perform calculations based on existing formula. The result shows that in term of direct cost, HVDC system which covers transmission line, converter and loses cost, yield in a range of 0,46 -0,60 USD\$/kWh for the capacity within $500-2000$ Mwe. While coal transportation cost is in the range of $0,544-0,645$ USD $\$ / k W h$ for long barge between 270 - 300 feet. Therefore, for the region of Indonesia which consist lots of islands and remote areas, power supply using HVDC transmission from area with more evolved electrical system could enable more economical, so that remote region also got excellent electrical services to improve the well-being and incomes of the population.

Keywords: HVDC, remote areas, power plant, effective, efficient.
\end{abstract}

\section{PENDAHULUAN}

Indonesia sebagai negara dengan wilayah yang luas, jumlah penduduk yang banyak dan beraneka latar dan profil wilayah menampilkan banyak tantangan untuk diatasi. Salah satunya adalah menyediakan

*Penulis korespondensi.

E-mail: edwaren@batan.go.id energi listrik dan mendistribusikannya ke setiap wilayah berpenduduk. Menghadapi tantangan tersebut membutuhkan berbagai upaya meliputi pembangunan fasilitas untuk mencapai tujuan sesuai dengan fungsi secara efektif dan efisien. Pembangunan fasilitas pembangkit listrik misalnya, tidak dapat 
dilakukan di setiap tempat atau suatu wilayah untuk menyediakan layanan prima[1].

Upaya untuk meningkatkan kesejahteraan penduduk di daerah terpencil membutuhkan layanan listrik yang andal dan berkualitas, sama seperti wilayah berpenduduk padat. Wilayah dengan beban listrik yang telah cukup besar dapat dipasok dengan berbagai opsi yang lebih luas seperti pembangkit listrik tenaga air (PLTA), pembangkit listrik tenaga uap dengan bahan bakar batubara (PLTU batubara), pembangkit listrik tenaga gas (PLTG), pembangkit listrik tenaga nuklir (PLTN) dan pembangkit besar dari jenis lainnya. Pembangkit listrik berukuran besar menawarkan biaya pembangkitan yang jauh lebih murah dibanding dengan pembangkit listrik kecil, terlebih lagi jika dibanding dengan pembangkit berbahan bakar diesel. Sementara pembangkit listrik berukuran besar tersebut tidak sesuai untuk dibangun di wilayah terpencil atau pulau kecil karena keterbatasan karakteristik bebannya.

PLTN dapat memproduksi listrik dalam skala besar yang sesuai bagi Indonesia sebagai negara berpenduduk keempat terbesar di dunia dengan karakteristik wilayah beragam dari segi kelayakan tapak. Sementara lokasi tapak PLTN membutuhkan kawasan geologi stabil. Jika di suatu pulau dibangun PLTN atau pembangkit jenis lain yang berskala besar, maka listriknya dapat dikirim ke pulau lain dengan sistem transmisi HVDC (High Voltage Direct Current). Jika suatu pulau yang membutuhkan listrik tidak ekonomis untuk memiliki pembangkit sendiri, maka pulau tersebut perlu dikaji apakah dapat dipasok dengan sistem transmisi HVDC yang lisriknya dapat bersumber dari berbagai jenis pembangkit, termasuk PLTN.

Wilayah yang selama ini dipasok dengan listrik bertenaga diesel biaya produksi listriknya sangat tinggi sehingga menguras banyak dana subsidi. Untuk mengurangi beban subsidi, pembangkit diesel di wilayah terpencil (beban rendah) hanya dioperasikan dalam jumlah jam terbatas, misalnya dari pukul lima sore sampai pukul sepuluh malam, atau lebih kurang selama lima jam setiap hari. Dengan demikian pemanfaatan listrik hanya untuk penerangan. Sedangkan untuk meningkatkan strata ekonomi dan kesejahteraan penduduk menuntut ketersediaan listrik selama 24 jam setiap hari.

Salah satu pemanfaatan HVDC adalah untuk menjangkau daerah terpencil dengan aliran listrik terus menerus selama 24 jam sehari sepanjang tahun dari sumber tenaga yang memadai, atau menjangkau sumber tenaga listrik dari lokasi yang jauh dari daerah demand secara efektif dan efisien[2].

Dengan sistem HVDC daerah terpencil tidak perlu membangkitkan listrik sendiri. Pasokan listrik diterima dari sumber yang jauh sehingga daerah tersebut dapat bergabung dengan daerah yang sistem listriknya sudah besar, biaya pembangkitannya lebih rendah, dan faktor ketersediaannya jauh lebih tinggi.

Penyaluran tenaga listrik jarak jauh dengan sistem HVDC mengurangi biaya secara signifikan dibanding sistem transmisi arus bolak balik tegangan tinggi (HVAC). Di banyak negara di dunia sistem ini diterapkan tidak hanya untuk penyaluran listrik daya besar, tetapi juga untuk daya kecil seperti sumber listrik dari energi baru dan terbarukan, misalnya energi angin dan energi surya $[3,4]$.

Makalah ini bertujuan untuk menguraikan aspek tekno ekonomi kelayakan pemanfaatan HVDC untuk penyaluran daya ke daerah terpencil atau pulau-pulau kecil di Indonesia. Metode yang digunakan adalah penelusuran pustaka dan penerapan formula untuk simulasi perkiraan biaya berdasarkan data sekunder dan hasil analisis yang telah dilakukan sebelumnya.

Hasil yang diharapkan dari analisis ini adalah diperolehnya nilai kuantitatif aspek tekno ekonomi pemanfaatan sistem HVDC sehingga dapat diketahui apakah sistem ini layak dikembangkan di Indonesia untuk mengatasi masalah keterbatasan sumberdaya. Pertimbangan didasarkan pada masalah dan kendala tekno ekonomi transmisi HVAC dan karakteristik berbagai jenis pembangkit untuk daerah terpencil dalam mendapatkan layanan listrik yang berkualitas. Hal tersebut disebabkan Indonesia mempunyai banyak daerah terpencil yang tidak ekonomis dibangun 
pembangkit berbahan bakar murah seperti PLTA besar, PLTU batubara dan PLTN.

\section{TEORI}

\subsection{Teknologi HVDC}

Pada paruh kedua abad lalu teknologi transmisi HVDC daya tinggi diperkenalkan, yang menawarkan dimensi baru untuk transmisi jarak jauh. Perkembangan ini dimulai dengan transmisi listrik pada kisaran kurang dari 100 MW dan sejak itu terus meningkat. Perangkat transmisi jarak jauh berkapasitas 3 GW dengan hanya satu pasang saluran bipolar DC telah menjadi entitas teknologi di bidang pengiriman daya listrik yang diterapkan di banyak negara saat ini.

Proyek HVDC 800 kV pertama di dunia ada di China yang mencapai rating transmisi 5000 MW dan akan berlanjut dengan 6000 - 7000 MW atau bahkan lebih dari tahap perencanaan semula sebesar 1000 MW). Secara umum, untuk jarak transmisi di atas $600 \mathrm{~km}$, transmisi HVDC lebih ekonomis daripada transmisi HVAC. Karena perkembangan ini, HVDC menjadi teknologi yang mapan dan dapat diandalkan[5].

\subsection{Visi Global Sistem HVDC}

Pada bulan Juni 2007, Siemens menerima pesanan dari perusahaan China Southern Power Grid, Guangzhou, untuk membangun sistem transmisi DC tegangan tinggi (HVDC) antara provinsi Yunnan di barat daya China dan provinsi Guangdong di pantai selatan bersama dengan mitra perusahaan lokal China. Sistem ini pertama di dunia menggunakan tegangan $\mathrm{DC} \pm 800$ kV. Proyek ini berkapasitas 5000 MW untuk memasok kawasan industri yng sedang berkembang pesat dari delta Sungai Pearl di provinsi Guangdong dan kota-kota besar dari Guangzhou dan Shenzhen. Listrik yang dihasilkan oleh beberapa PLTA dikirim dari Yunnan berjarak $1.400 \mathrm{~km}$ ke Guangzhou melalui saluran HVDC [6].

Diestimasi bahwa saluran HVDC ini akan mengurangi emisi $\mathrm{CO}_{2}$ lebih dari 30 juta ton per tahun. Hal ini terkait dengan jumlah gas buang polutif yang akan diproduksi jika tidak ada proyek tersebut, sebagai pengganti pembangunan pembangkit listrik fosil konvensional di Provinsi Guangdong untuk memasok jaringan regional[5]. Namun yang jauh lebih besar adalah rencana penyambungan jaringan listrik global. Interkoneksi ini akan menyatukan hampir seluruh daratan permukaan bumi dengan saluran HVDC.

Berbagai gagasan interkoneksi bertahap sistem grid lokal akan berintegrasi dengan saluran supergrid DC, meliputi sistem DC back-to-back, transmisi DC jarak jauh dan Flexible AC Transmission System (FACTS) untuk memperkuat sistem saluran AC yang telah ada. Sistem terintegrasi hibrida AC/DC memberikan keuntungan yang signifikan dalam hal teknologi, ekonomi dan keamanan. Sistem ini mengurangi biaya transmisi dan pelengkapnya, serta masalah yang berat pada sistem AC. Gambar 1 menunjukkan visi global interkoneksi sistem kelistrikan masa depan. Pendekatan ini juga merupakan langkah penting ke arah kelestarian lingkungan, sistem penyediaan tenaga listrik yang efektif untuk membantu mengurangi rugi-rugi transmisi, mengurangi emisi $\mathrm{CO}_{2}$ di seluruh dunia, dan menghindari kebutuhan pembangunan fasilitas pembangkit listrik di lokasi yang kurang memadai sebagai lokasi tapak[7].

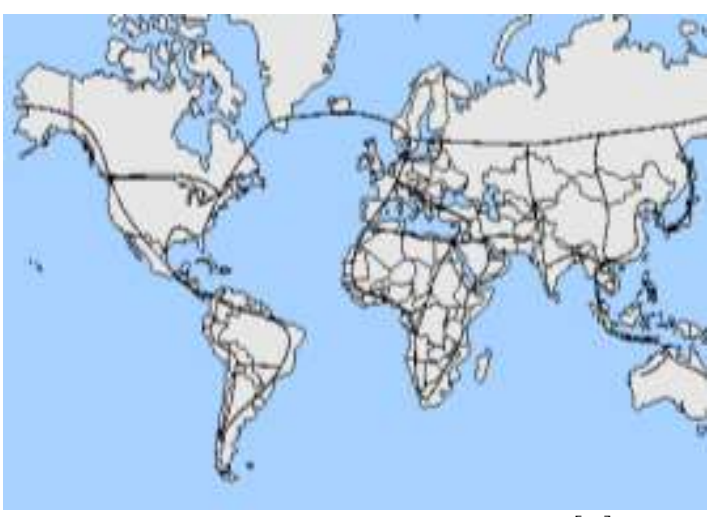

Gambar 1. HVDC Dalam Visi Global [5].

\subsection{Analisis Kemanfaatan Sistem HVDC}

Untuk mengevaluasi aspek ekonomi dari proyek transmisi diperlukan upaya kuantifikasi untuk mengukur proyek yang diusulkan mengarah ke ekonomi yang lebih 
efisien, menghilangkan kemacetan transmisi dan membawa manfaat kepada konsumen secara ekonomi[8].

Kajian tentang potensi keuntungan dan kerugian dalam memilih sistem penyediaan tenaga listrik untuk suatu wilayah meliputi opsi apakah membangun pembangkit listrik berukuran kecil, penyaluran dengan HVAC atau penyaluran dengan HVDC dari wilayah yang menyediakan pembangkit berukuran besar. Kajian bertujuan untuk mendapatkan nilai tekno ekonomi paling optimal, yaitu andal, efektif dan efisien. Akan dibandingkan antara opsi pembangunan pembangkit listrik skala besar dengan sistem HVDC dan pembangunan PLTU di dekat wilayah demand.

Sistem HVDC menawarkan keuntungan maksimal, yaitu dapat digunakan untuk sistem interkoneksi dan untuk mengatur aliran listrik.[5] Manfaat utama dari HVDC adalah kemampuannya untuk memblokir arus gangguan yang tidak mungkin dilakukan dengan saluran sinkron AC. Selain itu, HVDC efektif mendukung sistem AC di sekitarnya dalam kondisi gangguan sementara dan berfungsi sebagai firewall terhadap gangguan cascading. Keuntungan paling besar yang ditawarkan HVDC adalah dapat digunakan untuk sistem interkoneksi dan lebih unggul dalam mengatur aliran daya[7].

Sistem interkoneksi sinkron AC yang besar dengan transmisi jarak jauh menghadapi masalah teknis seperti terangkum dalam Gambar 2.

Masalah utama terjadi dalam aliran beban, osilasi sistem dan osilasi antar wilayah. Jika sistem memiliki ekstensi geografis yang luas dan harus mengirimkan daya besar jarak jauh, masalah tegangan dan stabilitas akan timbul. Sistem interkoneksi yang besar menghadapi batasan utama pada dua hal berikut $[9,10]$ :

1. Masalah pada sistem interkoneksi,

berupa:

- Aliran beban (kemacetan transmisi)

- Pengaturan frekuensi

- Stabilitas tegangan

- Stabilitas osilasi

- Osilasi antar wilayah

- Risiko blackout karena efek cascading

- Interaksi fisik antara sistem daya.

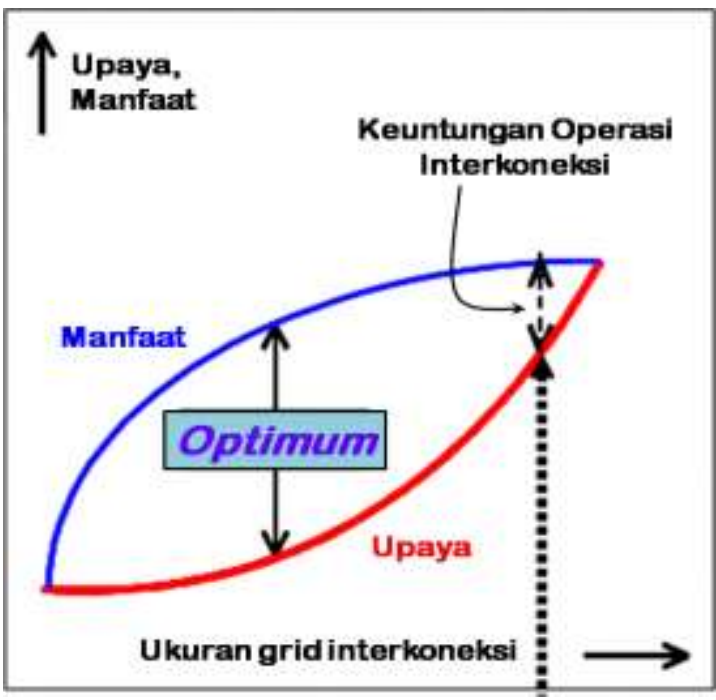

Gambar 2. Sistem Interkoneksi Besar AC - Manfaat Versus Upaya [5].

2. Masalah pada sistem transmisi jarak jauh, berupa:

- Stabilitas tegangan

- Masalah daya reaktif

- Stabilitas keadaan tunak (steady-state)

- Stabilitas transien

- Osilasi subsinkron

Tabel 1: Biaya Pembangkitan Rata-rata PLN

\begin{tabular}{rrrrrrrr}
\hline \multirow{2}{*}{ Tahun } & \multicolumn{3}{c}{ Bahanbakar Minyak (Rp/liter) } & $\begin{array}{r}\text { Batubara } \\
\text { (Rp/kg) }\end{array}$ & $\begin{array}{r}\text { Gas alam } \\
(\mathrm{Rp} / \mathrm{MSCF})\end{array}$ & $\begin{array}{r}\text { Panasbumi } \\
(\mathrm{Rp} / \mathrm{kWh})\end{array}$ \\
\cline { 2 - 4 } & HSD & IDO & MFO & Rata-rata & & \\
2006 & $5.629,21$ & $5.350,64$ & $3.534,53$ & $4.838,13$ & 335,81 & $24.185,59$ & 505,40 \\
2007 & $5.349,61$ & $5.275,42$ & $3.563,41$ & $4.881,43$ & 338,76 & $23.480,99$ & 538,31 \\
2008 & $8.738,25$ & $8.650,23$ & $5.762,10$ & $7.906,23$ & 489,23 & $29.128,16$ & 658,73 \\
2009 & $5.601,07$ & $5.552,33$ & $4.315,86$ & $5.186,76$ & 732,32 & $37.998,48$ & 559,63 \\
2010 & $6.050,35$ & $5.870,37$ & $5.150,42$ & $5.815,65$ & 656,71 & $42.287,16$ & 653,52 \\
2011 & $8.513,27$ & $8.229,36$ & $7.027,21$ & $8.188,09$ & 698,62 & $39.867,31$ & 737,04 \\
2012 & $8.949,35$ & $8.954,18$ & $7.319,67$ & $8.629,80$ & 746,22 & $63.757,56$ & 693,05 \\
2013 & $9.446,64$ & $9.149,48$ & $7.604,40$ & $9.127,05$ & 938,56 & $92.185,45$ & 858,48 \\
2014 & $10.320,86$ & $10.823,96$ & $7.108,43$ & $9.847,04$ & $1.004,50$ & $105.876,17$ & $1.012,00$ \\
\hline
\end{tabular}


Masalah sistem tersebut dapat diperbaiki dengan aplikasi sistem DC yang berbasis pada sistem komponen elektronika daya[10]. Transmisi DC mempunyai keunggulan sebagai berikut:

- Untuk saluran udara dengan panjang lebih dari $600 \mathrm{~km}$ dan saluran bawah laut lebih dari $50 \mathrm{~km}$, transmisi DC membutuhkan biaya lebih rendah[4]. Penghematan ini meningkat dengan cukup memasang hanya satu konduktor saluran DC sebagai pengganti tiga konduktor saluran AC. Keuntungan ini mengungguli kompensasi untuk biaya stasiun konverter AC/DC.

- Saluran transmisi DC mempunyai rugirugi daya yang lebih kecil, sedangkan rugi-rugi stasiun konverter normalnya sekitar $0,6 \%$ per stasiun, dan rugi-rugi kabel DC hanya sekitar 0,3 - 0,4\% per $100 \mathrm{~km}[7]$.

- Kabel AC yang panjang menghasilkan daya reaktif yang besar, membutuhkan reaktor shunt pada kedua ujungnya. Arus daya reaktif melemahkan kemampuan transmisi daya aktif.

- Saluran DC dapat menghubungkan dua grid listrik yang tidak sinkron pada kasus di mana sistem tidak dapat ditetapkan sebagai interkoneksi asinkron.

- Kemudahan pengaturan yang tinggi pada sistem DC dapat dimanfaatkan untuk meningkatkan kondisi operasi grid terinterkoneksi.

- Transmisi DC paling sesuai untuk transmisi kabel laut, karena rugi-rugi daya jauh lebih rendah dibanding ttransmisi AC.

Hal ini berdayaguna tinggi bagi negara kepulauan seperti Indonesia untuk menginterkoneksi antara satu pulau dengan pulau lainnya.

Potensi kerugian menggunakan HVDC dibanding teknologi HVAC meliputi: (1) biaya yang lebih tinggi untuk saluran jarak pendek karena diperlukan biaya peralatan untuk mengkonversi listrik AC ke DC dan DC ke AC yang digunakan oleh penduduk, dan (2) kurangnya manfaat listrik untuk konsumen yang tinggal di sepanjang saluran karena antara saluran tersebut umumnya tidak terhubung ke saluran listrik lokal, kecuali dipasang stasiun konverter di lokasi tersebut.
Biaya penyaluran melalui sistem HVDC tergantung pada besarnya daya, jarak pengiriman, dan jenis transmisi. Besaran ini dapat diestimasi dengan Formula yang diperoleh berdasarkan pemodelan stokhastik, meliputi penerapan formula masing-masing biaya saluran transmisi udara, kabel laut dan stasiun konverter pada kedua sisi pengirim dan penerima, sebagai berikut $[11,12]$ :

- biaya saluran udara:

$\mathrm{C}_{\mathrm{OH}}=0,2165 \times \mathrm{P}^{0.29} \times \mathrm{L}_{\mathrm{OH}}$

- biaya kabel laut:

$\mathrm{C}_{\mathrm{SC}}=0,107 \times \mathrm{P}^{0.44} \times \mathrm{L}_{\mathrm{SC}}$

- dan biaya konverter:

$\mathrm{C}_{\text {Conv }}=3,306 \times \mathrm{P}^{0.65}$

dimana $\mathrm{C}_{\mathrm{OH}}$ adalah biaya saluran transmisi udara (juta US\$); $\mathrm{C}_{\mathrm{SC}}$ adalah biaya saluran kabel laut (juta US\$); $\mathrm{C}_{\mathrm{Conv}}$ adalah biaya konverter (juta US\$); $\mathrm{P}$ adalah kapasitas daya (MW); $\mathrm{L}_{\mathrm{OH}}$ adalah panjang saluran transmisi udara $(\mathrm{km}) ; \mathrm{L}_{\mathrm{SC}}$ adalah panjang saluran kabel laut (km).

\section{DATA DAN ASUMSI}

Biaya pembangkitan energi diperoleh dari data dan asumsi sistem pembangkitan yang telah tercatat dari sumber yang berkompeten. Pada Tabel 1 ditunjukkan informasi dari PT PLN, bahwa biaya pembangkitan listrik dengan bahan bakar batubara paling rendah, sehingga dari jenis yang ditampilkan tersebut batubara paling potensial untuk dikembangkan.

Berdasarkan informasi dari Tabel 1 besarnya biaya energi adalah seperti ditunjukkan pada Tabel 2.

Tabel 2. Biaya Rata-rata Energi Listrik dari Jenis Sumber

\begin{tabular}{lcc}
\hline Sumber Energi & Biaya Energi (US\$/MWh) \\
\hline PLTU Batubara & 55,87 \\
PLT Gas & 222,52 & \\
PLT Diesel & 235,72 & \\
\hline \multicolumn{1}{c}{ PLTN } & adalah & pembangkit yang
\end{tabular}
potensial dan memiliki daya saing atas biaya pada beban dasar seperti halnya pembangkit 
batubara. Pembangkit ini tidak perlu ditampilkan di sini karena analisis ditujukan untuk evaluasi keekonomian lokasi pembangkitan yang terkait untuk pembanding.

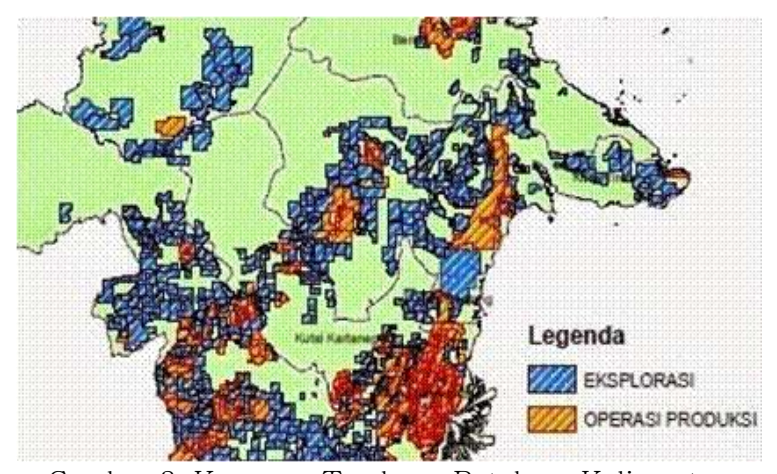

Gambar 3. Kawasan Tambang Batubara Kalimantan Timur[15].

Untuk menganalisis kemanfaatan sistem HVDC didalam makalah ini dibahas suatu kasus yang dikembangkan berdasarkan asumsi dan data yang tersedia dari berbagai sumber dan pengukuran kawasan terkait melalui informasi digital seperti google maps, google earth, dan pemetaan sistem yang telah tersedia dari beberapa sumber. Pembangkit listrik dapat ditempatkan di mulut tambang (Gambar 3), atau dekat tambang batubara di pesisir, atau dengan pembangunan PLTN Kalimantan Timur yang memungkinkan dari segi kelayakan tapak karena Kalimantan Timur termasuk kawasan geologi stabil[14].

Kasus yang diangkat disini adalah transmisi Kalimantan - Sulawesi. Opsi penyediaan listrik yang dikonteskan adalah pembangunan PLTU batubara di Kalimantan Timur disertai saluran HVDC ke Sulawesi dan pembangunan PLTU batubara di Sulawesi. Dengan asumsi sementara lokasi tapak pembangunan PLTN paling layak di antara keduanya adalah di Kalimantan Timur berdasarkan stabilitas geologinya. PLT Gas dan PLTD tidak dikonteskan mengingat biaya produksinya jauh lebih tinggi daripada PLTU Batubara.

Biaya angkut batubara mengacu Peraturan Direktur Jenderal Mineral dan Batubara No. 644.K/30/DJB/2013 dirumuskan menurut persamaan yang tercantum pada Tabel 3 sebagai berikut:
$\mathrm{BB}=$ Indeks $\mathrm{A} \times(\mathrm{JT})+$ Indeks $\mathrm{B}$

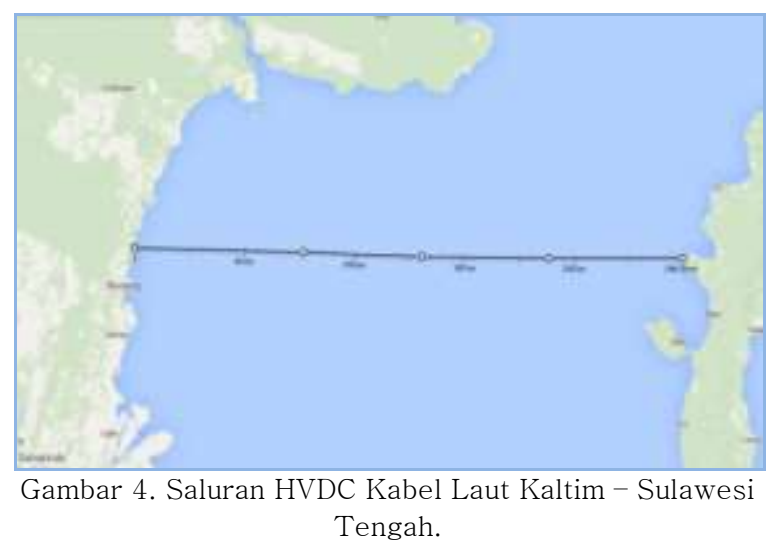

Indeks A dan Indeks B adalah seperti tertera pada Tabel 3. Jarak tempuh terhitung dalam mil laut (= 1852 meter).

Sistem transmisi HVDC dari Kalimantan memiliki beberapa opsi, keseluruhan melalui kabel laut seperti pada Gambar 4, dan gabungan dari transmisi udara dan transmisi kabel laut. Untuk transmisi keseluruhan kabel laut pemilihan lokasi diasumsikan di sekitar Kota Bontang, sedangkan gabungan transmisi kabel laut dan transmisi udara mengambil lokasi pembangkitan mendekati semenanjung Kutai Timur seperti ditunjukkan pada Gambar 5.

Dari lokasi ini daya listrik dikirim melalui saluran transmisi udara hingga ujung Semenanjung dan selanjutnya melalui kabel

laut sepanjang $121 \mathrm{~km}$ ke Pesisir Sulawesi Tengah.

Biaya penggunaan sistem HVDC didasarkan pada beberapa parameter, yakni panjang saluran, jenis saluran (transmisi kabel laut atau saluran udara), kapasitas daya, umur operasi dan teknologi yang digunakan. Teknologi ini telah mapan dan memiliki catatan pelayanan yang cukup panjang. Pada prinsipnya teknologi ini sama dengan generasi pertama dari kabel listrik

Tabel 3. Biaya Transportasi Batubara

\begin{tabular}{cc}
\hline $\begin{array}{c}\text { Ukuran } \\
\text { tongkang }(\text { feet })\end{array}$ & Persamaan \\
\hline$<270$ & $\mathrm{BB}=0,0221(\mathrm{JT})+3,7406$ \\
$270-330$ & $\mathrm{BB}=0,0184(\mathrm{JT})+3,1172$ \\
$>330$ & $\mathrm{BB}=0,0154(\mathrm{JT})+2,6022$ \\
\hline
\end{tabular}

$\mathrm{BB}=$ biaya tongkang (USD/ton);

$\mathrm{JT}=$ jarak tempuh (mil laut) 
tegangan tinggi lebih dari 100 tahun yang lalu. Dari pengalaman ketahanan kabel berisolasi

terbungkus pita kertas sangat baik. Secara umum kabel tegangan tinggi memiliki umur terbukti lebih dari 70 tahun. Sejumlah besar kabel laut sukses dalam pelayanan berumur lebih dari 50 tahun[16].

Meskipun kabel laut untuk transmisi HVDC memiliki sejarah yang lebih pendek, kabel laut pertama Gotland di Swedia mulai beroperasi sejak 50 tahun yang lalu, namun riwayat proses penuaan kabel laut HVDC tidak menunjukkan perbedaan terhadap kabel laut HVAC. Dengan demikian tidak ada alasan bahwa umur kabel laut HVDC lebih pendek dari kabel AC berisolasi kertas, yaitu minimal 50-60 tahun [16].

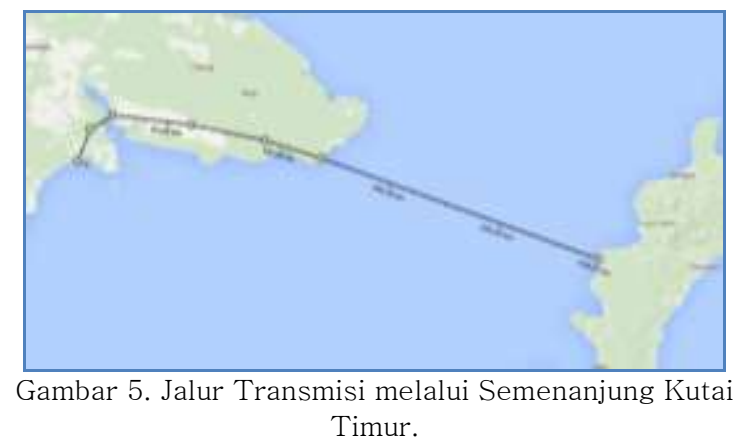

\section{HASIL DAN PEMBAHASAN}

Biaya angkut dengan tongkang berdasarkan Peraturan Direktur Jenderal Mineral dan Batubara No. 644.K/30/DJB/2013 didasarkan atas formula penentuan biaya per satuan volume yang dikonversi menjadi per satuan energi listrik[16]. Dari persamaan yang mengandung Indeks $A$ dan Indeks $B$ pada Tabel 3 serta dengan asumsi bahwa nilai kalor dan heat rate seperti disebutkan sebelumnya, maka dapat dibuat persamaan untuk menentukan biaya angkut batubara dalam satuan $\mathbf{\Phi} / \mathrm{kWh}$. Diasumsikan pula bahwa nilai kalor batubara adalah 5.300 $\mathrm{kcal} / \mathrm{kg}$ dan heat rate rata-rata pada pembangkit $2.500 \mathrm{kcal} / \mathrm{kWh}$.

Angka-angka pada Tabel 1 dikonversi menjadi besaran biaya per satuan energi sehingga menjadi angka-angka biaya per satuan energi. Jarak tempuh tongkang antara Kalimantan Timur ke pantai terdekat di
Sulawesi adalah $250 \mathrm{~km}$, maka biaya transportasi batubara dengan jarak tempuh $250 \mathrm{~km}$ berdasarkan Peraturan Direktur Jenderal Mineral dan Batubara No. 644.K/30/DJB/2013 menurut Persamaan (4) adalah seperti ditunjukkan pada Tabel 4 .

Tabel 4. Biaya Transportasi Batubara[17]

\begin{tabular}{cc}
\hline $\begin{array}{c}\text { Ukuran Tongkang } \\
\text { (feet) }\end{array}$ & Biaya (US $\phi / k W h)$ \\
\hline$<270$ & 0,32 \\
$270-330$ & 0,26 \\
$>330$ & 0,22 \\
\hline
\end{tabular}

Selain biaya angkut tongkang, proses transportasi batubara masih mengeluarkan biaya tambahan berupa[17]:

a) biaya transshipment: $4 \mathrm{USD} / \mathrm{ton}$,

b) biaya surveyor: 0,25 USD/ton, dan

c) biaya asuransi: 0,8\%.

Berdasar data tersebut dihasilkan biaya transportasi batubara seperti ditunjukkan pada Tabel 5. Biaya angkut tongkang batubara $B B$ berdasarkan dari persamaan yang mengandung Indeks $A$ dan Indeks $B$ pada Tabel 3, maka dengan menyertakan biaya tambahan dapat dibuat persamaan untuk menentukan biaya angkut batubara dalam satuan USD $\mathbf{\phi} / \mathrm{kWh}$, dan menyebabkan revisi Persamaan (4) menjadi Persamaan (5), yaitu:

$$
\begin{aligned}
& \mathrm{BB}=\left\{\text { Indeks } \mathrm{A} \times \frac{\mathrm{Jarak}(\text { mile })}{1,852}+\text { Indeks B }\right\} \\
& \times \frac{2,5}{5300}+\text { Biaya transshipment }+4,25+0,8 \%
\end{aligned}
$$

Dengan demikian besaran biaya pada Tabel 4 dapat dilengkapi menjadi Tabel 5 sebagai berikut:

Tabel 5. Biaya Total Transportasi Batubara

\begin{tabular}{cc}
\hline $\begin{array}{c}\text { Ukuran tongkang } \\
(\text { feet })\end{array}$ & $\begin{array}{c}\text { Biaya total transportasi } \\
(\mathrm{USD} \phi / \mathrm{kWh})\end{array}$ \\
\hline$<270$ & 0,645 \\
$270-330$ & 0,585 \\
$>330$ & 0,544 \\
\hline
\end{tabular}

Analisis tentang kelayakan ekonomi sistem HVDC dapat disederhanakan dengan membandingkan biaya angkut batubara dari Kalimantan Timur ke Sulawesi pada jarak terdekat. 
Tabel 7. Biaya Konverter

\begin{tabular}{ccc}
\hline \multirow{2}{*}{$\begin{array}{c}\text { Kapasitas } \\
(\mathrm{MWe})\end{array}$} & \multicolumn{2}{c}{ Biaya Converter } \\
\cline { 2 - 3 } & (USD/MWyr) & $(\mathrm{USD} \phi / \mathrm{kWh})$ \\
\hline 500 & 9.389 & 0,11 \\
1.000 & 7.366 & 0,08 \\
1.500 & 6.392 & 0,07 \\
2.000 & 5.779 & 0,07 \\
\hline
\end{tabular}

Persamaan (2) merumuskan biaya saluran kabel laut berdasarkan kapasitas daya penyaluran. Dengan asumsi bahwa masa operasi kabel selama 50 tahun maka dapat dirumuskan biaya penyaluran per satuan energi terkirim dengan kabel laut seperti pada Persamaan (6).

$$
\mathrm{c}^{\prime} \mathrm{SC}=\frac{107 \times \mathrm{P}^{(-0.56)} \times \mathrm{L}_{\mathrm{SC}} \times 1000}{50}
$$

$\mathrm{C}_{\mathrm{sc}}^{\prime}=$ biaya per satuan energi terkirim.

Dengan demikian diperoleh estimasi biaya saluran transmisi HVDC per satuan energi terkirim adalah seperti ditunjukkan pada Tabel 6.

Tabel 6: Biaya Saluran Transmisi HVDC

\begin{tabular}{rrrr}
\hline \multirow{2}{*}{$\begin{array}{r}\text { Kapasitas } \\
(\mathrm{MWe})\end{array}$} & $\begin{array}{c}\text { Energi } \\
(\mathrm{MWyr})\end{array}$ & \multicolumn{2}{c}{ Biaya Transmisi } \\
\cline { 3 - 4 } & $(\mathrm{USD} / \mathrm{MWyr})$ & $(\mathrm{USD} \phi / \mathrm{kWh})$ \\
\hline 500 & 15.000 & 16.479 & 0,19 \\
1.000 & 30.000 & 11.178 & 0,13 \\
1.500 & 45.000 & 8.907 & 0,10 \\
2.000 & 60.000 & 7.582 & 0,09 \\
\hline
\end{tabular}

Selain untuk saluran transmisi, sistem HVDC membutuhkan konverter pada kedua sisi pengirim dan penerima. Biaya konverter dirumuskan berdasarkan Persamaan (3). Selanjutnya dari Persamaan (3) diperoleh Persamaan (7) yang memberikan nilai untuk biaya konversi persatuan energi (USD\$/kWh), dengan asumsi bahwa masa operasi konverter adalah 40 tahun, yaitu:

$$
\mathrm{C}^{\prime}{ }_{\text {Conv }}=0,943 \times \mathrm{P}^{(-0.35)}
$$

Persamaan (7) memberikan nilai untuk biaya konverter seperti ditunjukkan pada Tabel 7 berikut.

Biaya total sistem transmisi HVDC adalah biaya saluran pada Tabel 6 dan biaya konverter pada Tabel 7 , sehingga diperoleh Tabel 8 yang menunjukkan biaya total sistem transmisi HVDC. Rugi-rugi energi dalam transportasi batubara diabaikan, 120

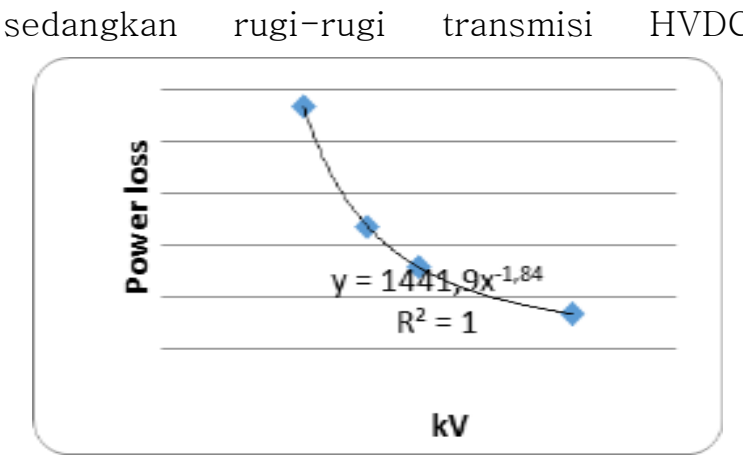

Gambar 6. Rugi-rugi transmisi HVDC pada daya 200 MW

dengan daya $200 \mathrm{MW}$, tegangan $275 \mathrm{kV}$ dan panjang transmisi $200 \mathrm{~km}$ terhitung sebesar 4,7\% (berdasarkan hasil ekstrapolasi vendor sistem HVDC Siemens) dan rugi-rugi konverter sebesar 0,72\% [18,19]. Maka total rugi-rugi sistem transmisi HVDC dalam kasus ini menjadi 5,42\%. Untuk menyamakan semua besaran, nilai rugi-rugi dalam \% dikonversi menjadi USD $\varnothing / \mathrm{kWh}$ sebagai biaya produksi listriknya, yang dalam hal ini mengacu ke Tabel 2. Pembangkit yang diambil di sini adalah 500 MW ke bawah, sehinggga total rugi-rugi adalah 0,303 $\mathrm{USD} \notin / \mathrm{kWh}$.

Tabel 8: Biaya Total Sistem Transmisi HVDC

\begin{tabular}{rrrrr}
\hline \multirow{2}{*}{$\begin{array}{r}\text { Kapasitas } \\
\text { (MWe) }\end{array}$} & Kabel laut Konverter & $\begin{array}{r}\text { Rugi- } \\
\text { rugi }\end{array}$ & Total \\
\hline 500 & 0,19 & 0,11 & 0,30 & 0,60 \\
1000 & 0,13 & 0,08 & 0,30 & 0,51 \\
1500 & 0,10 & 0,07 & 0,30 & 0,47 \\
2000 & 0,09 & 0,07 & 0,30 & 0,46 \\
\hline
\end{tabular}

Melihat perbandingan hasil perhitungan biaya kedua moda pengiriman energi tersebut tampak perbedaan tidak signifikan untuk pengiriman daya sampai 500 MW. Sedangkan untuk kapasitas daya lebih besar perbedaan biaya semakin besar. Untuk pengiriman daya dengan pilihan yang lebih kritis dan efisien adalah dengan menempatkan lokasi pembangkit dekat Semenanjung Kutai Timur, sehingga sistem transmisi menggunakan gabungan saluran udara dan kabel laut seperti ditunjukkan pada Gambar 5 yang menghasilkan perhitungan biaya seperti ditunjukkan pada Tabel 8. 
Tabel 8. Biaya untuk Opsi Jalur Transmisi HVDC Melalui Semenanjung Kutai Timur

\begin{tabular}{rrrr}
\hline $\begin{array}{r}\text { Kap. } \\
(\mathrm{MWe})\end{array}$ & $\begin{array}{r}\text { Energi } \\
(\text { GWh })\end{array}$ & $\begin{array}{r}\text { Biaya Total } \\
(\text { MUSD })\end{array}$ & $\begin{array}{r}\text { Biaya satuan } \\
(\mathrm{USD} \phi / \mathrm{kWh})\end{array}$ \\
\hline 500 & 131.400 & 363,82 & 0,28 \\
1.000 & 262.800 & 392,30 & 0,15 \\
\hline
\end{tabular}

Biaya satuan pada Tabel 8 bila ditambahkan dengan rugi-rugi daya untuk kedua level kapasitas 500 dan 1000 MW masing-masing akan menjadi 0,58 dan 0,45 $\mathrm{USD} \not / \mathrm{kWh}$. Dengan demikian perbandingan biaya langsung antara transmisi HVDC dan pengangkutan batubara adalah seperti pada Tabel 9.

Perbandingan biaya pengiriman energi antara pengangkutan batubara dan transmisi HVDC tidak persis sama seperti dalam satu satuan moda pengiriman. Namun kurva biaya dapat memberikan gambaran lebih jelas bahwa untuk kapasitas lebih besar HVDC semakin ekonomis.

Hasil analisis biaya pengiriman energi dari Kalimantan Timur ke Sulawesi dapat menunjukkan perbedaan, yang mana perbandingan antara sistem HVDC dan transportasi batubara berada antara 0,72 sampai 1,10. Angka ini tergantung pada ukuran tongkang dan kapasitas daya, dimana semakin besar semakin efisien. Untuk perencanaan jangka panjang sistem HVDC akan semakin menarik karena memangkas berbagai biaya dan masalah lain yang tak terduga.

Tabel 9. Perbandingan Biaya untuk Opsi Pengangkutan Batubara dan Sistem Transmisi HVDC

\begin{tabular}{|c|c|c|c|}
\hline \multicolumn{2}{|c|}{ Transportasi Batubara } & \multicolumn{2}{|c|}{ Sistem HVDC } \\
\hline $\begin{array}{r}\text { Ukuran } \\
\text { tongkang } \\
\text { (feet) }\end{array}$ & $\begin{array}{r}\text { Biaya } \\
\text { satuan } \\
\mathrm{USD} \phi / \mathrm{kWh}\end{array}$ & $\begin{array}{r}\text { Kapasitas } \\
\text { MW }\end{array}$ & $\begin{array}{l}\text { Biaya satuan } \\
\text { (USD } \phi / \mathrm{kWh})\end{array}$ \\
\hline$<270$ & 0,645 & 500 & 0,60 \\
\hline $270-330$ & 0,585 & 1000 & 0,51 \\
\hline$>330$ & 0,544 & 1500 & 0,47 \\
\hline
\end{tabular}

pembangunan PLTU batubara di Sulawesi juga membutuhkan biaya tambahan seperti pembangunan sarana dan prasarana pelabuhan batubara, prasarana jalan raya dan fasilitas pendukung lainnya. Di samping itu gangguan transportasi batubara tidak jarang terjadi seperti halangan bongkar muat tongkang akibat cuaca buruk dan lain sebagainya yang mungkin menjadi biaya tak langsung dalam kasus ini.

\section{KESIMPULAN}

Dari pertimbangan aspek keuntungan dan biaya, kebutuhan akan transmisi arus searah (DC) pada zaman interkoneksi yang luas semakin menguat. Dari kasus yang diangkat pada penelitian ini diperoleh kesimpulan bahwa dari segi biaya langsung, sistem HVDC yang meliputi biaya saluran transmisi, konverter dan rugi-rugi daya berkisar antara 0,46-0,60 USD $\not / k W h$ untuk kapasitas daya berkisar antara 500 - 2000 MWe. Sedangkan biaya angkut batubara berkisar antara 0,544 - 0,645 USD $\varnothing / \mathrm{kWh}$ untuk tongkang berukuran panjang antara 270 - 330 feet. Namun biaya angkut batubara tersebut belum meliputi biaya pembangunan infrastruktur seperti pelabuhan jalan raya dan sebagainya. Meskipun biaya transportasi batubara dan sistem HVDC berbeda tipis untuk kapasitas daya 500 MW, namun untuk kapasitas semakin besar perbedaan biaya antara kedua opsi semakin besar. Sedangkan transmisi HVDC melalui gabungan saluran udara dan kabel laut terhadap kabel laut semata, perbedaan biayanya cukup signifikan yaitu dengan perbandingan $0,28: 0,32$ untuk kapasitas 500 MW, dan selisih biaya akan semakin besar untuk kapasitas daya yang semakin besar. Keuntungan lain dengan sistem HVDC adalah bahwa sistem transmisi HVDC lebih andal, tahan cuaca buruk dan lebih menjamin kontinuitas pasokan daya pada daerah demand.

\section{DAFTAR ACUAN}

[1] P. Tuson. "HVDC Strengthening in Southern Africa”. IEEE PES Power Africa 2007 Conference and Exposition, Johannesburg, South Africa, 16-20 July 2007.

[2] T. Drobik. "High-voltage Direct Current Transmission Lines". IEEE Conference Publishing, ul. Pulaskiego 32/13, 46-100 Namyslow, Poland.

[3] "Report of The Working Group on Power for Twelfth Plan (2012-17)", Government of India, Ministry of Power, New Delhi, January 2012. 
[4] A. Hermansson. "Simulation of Line Fault Locator on HVDC Light Electrode Line". Bachelor's Thesis, Electrical Engineering, Electric Power Technology, Department of Engineering Science, University West, S-461 86 Trollhättan, SWEDEN, August 10, 2010.

[5] D. Retzmann and K. Uecker. "Benefit of HVDC and FACTS for Sustainability and Security of Power Supply". IEEE Power Africa Conference and Exposition, July 16 - 20, 2007.

[6] "High Voltage Direct Current Transmission Proven Technology for Power Exchange" Answers for Energy”. Siemens.

[7] J. Kreusel and D. Retzmann. "Integrated AC/DC Transmission Systems - Benefits of Power Electronics for Security and Sustainability of Power Supply". PSCC 2008 Survey Paper ABB, Siemens - Germany, 2008.

[8] S. Wang and L. Trinh. "Economic Assessment of HVDC Project in Deregulated Energy Markets". 2008. [Online]. Available: http://ieeexplore.ieee. org/iel5/4511470/4523365/04523373.pdf?arnum ber $=4523373$.

[9] W. Breuer, D. Povh, and D. Retzmann, E., "Trends for future HVDC Applications". Proceeding of The $16^{\text {th }}$ Conference of the Electric Power Supply Industri, 6 - 10 November 2006, Mumbai, India, 2006.

[10] W. Breuer, D. Povh, D. Retzmann, E. Teltsch, and X. Lei. "Role of HVDC and FACTS in future Power Systems". Proceeding of $15^{\text {th }}$ Conference of the Electric Power Supply Industri, 18 - 22 October 2004, Beijing, China, 2004.

[11] E. Liun dan Suparman. "Cost Estimation of HVDC Transmission System of Bangka's NPP Candidates". Proceeding of $4^{\text {th }}$ International Conference on Advances in Nuclear Science and Engineering (ICANSE), 16 - 19 September 2013, Denpasar, Indonesia, 2013

[12] E. Liun. "Stochastic Methodology to Estimate Costs of HVDC Transmission System”. Journal of Energy and Power Sources, Vol. 2, No. 3, 2015, pp. 90-98.

[13] "Statistik PLN 2014”. PT PLN (Persero), Jakarta, 2015.

[14] "Laporan Pemetaan Geologi Bersistem dan Potensi Energi dan Sumberdaya Mineral Perairan Muara Sungai Berau Kalimantan Timur". Tim Muara Sungai Berau, Departemen Energi dan Sumer Daya Mineral Badan Penelitian dan Pengembangan Energi dan Sumberdaya Mineral, Pusat Penelitian dan Pengembangan Geologi Kelautan, 2005.

[15] S. Agustio. "Industri Keruk Batubara dan Bencana Ekologi di Kalimantan Timur". [Online]. Tersedia:https://www.google.co.id/webhp?sourc eid=chromeinstant\&rlz=1C1CHZL_idID712ID714 \&ion=1\&esp v=2\&ie=UTF-8\#, diakses 11 Maret 2015.

[16] J. E. Skog dan J. E. Skog. "HVDC Transmission and Lifetime Expectancy". The document is sent to D. Bos, J.M. van den Berg, Øivind Rue, Kåre Schjetne, Herman Bannink, Gunnar Løvås. 16 Januari 2016. [Online]. Tersedia: http://www.tennet.eu/nl/filebadmin/downloads/A bout_Tennet/Publications/Other_Publications/Ap plication\%20for\%20Norned/plugin-19-B7-HVD C_Transmission_and_Lifetime_Expectancy_tcm 4 1-12302.pdf,16 Januari 2016.

[17] Keputusan Direktur Jenderal Mineral Dan Batubara Nomor: 459.K/32/DJB/2015 tentang Biaya Produksi Untuk Penentuan Harga Batubara, Direktur Jenderal Mineral Dan Batubara, Kementerian Energi Dan Sumber Daya Mineral Republik Indonesia.

[18] "Fact Sheet High-Voltage Direct Current Transmission (HVDC)”. Siemens. July 2012.

[19] G. Holdmann, et al. "Small-Scale High Voltage Direct Current". The Alaska Center for Energy and Power, University of Alaska Fairbanks, 814 Alumni Drive, 2013. 